\title{
A southern bottlenose whale eXamined in the Antarctic
}

\author{
Robert Clarke ${ }^{1}$
}

\begin{abstract}
Aвstract: This paper mainly concerns the dissection of a lactating female southern bottlenose whale Hyperoodon planifrons especially shot and worked up for the author in the Antarctic $61^{\circ} 09^{\prime} \mathrm{S}, 86^{\circ} 44^{\prime} \mathrm{E}$ on 10 March 1948 . The skeleton is in the British Museum (Natural History). A comparison with what is known of the female northern bottlenose whale H. ampullatus shows no differences in morphometry, body colour, external characters, digestive system and reproductive system, parasites and the vertebral formula and the digital formula of the flipper. There remain acknowledged differences in the skull which may be reduced or perhaps even disappear when further comparisons are attempted between skulls from males and females of similar ages. There is also the confusion when identifying ziphiid whales at sea. These observations have suggested to the author that there may be only one Hyperoodon species with a continuous distribution north and south . But Dalebout et al, (2004), applying DNA sequencies in molecular taxonomy, have now shown that all 21 species of ziphiid whales are valid.
\end{abstract}

RESUMEN: Este trabajo por la mayor parte describe la disección de una hembra lactando de una ballena nariz de botella del sur Hyperoodon planifrons especialmente matado y trabajado para el autor en el Antártico $61^{\circ} 09^{\prime} \mathrm{S}, 86^{\circ} 44^{\prime} \mathrm{E}$ el 10 de marzo de 1948. El esqueleto está en el Museo Británico (Historia Natural). Una comparación con lo que se sabe de la hembra de la ballena nariz de botella del norte (H. ampullatus), enseña que no hay diferencias en morfometría, color del cuerpo, caracteres externos, el sistema digestivo y el sistema reproductivo, parásitos, la formula vertebral y la fórmula digital de las aletas. Quedan diferencias reconocidas en el cráneo, las cuales pueden tal vez ser reducido o tal vez desaparecer cuando más comparaciones sean tratadas entre cráneos de machos y hembras de edades similares. También hay la confusión cuando se está identificando ballenas de la familia Ziphiidae en el mar. Estas observaciones han sugerido al autor que puede haber solamente una especie de Hyperoodon con una distribución continua en el norte y el sur. Pero Dalebout et al. (2004), aplicando secuencias de ADN en taxonomía molecular, han demostrado ahora que todas las 21 especies de ballenas de la familia Ziphiidae son válidas.

KEYwords: Hyperoodon planifrons, H. ampullatus, Indopacetus pacificus. Identification of ziphiid whales at sea, distribution, taxonomy, anatomy.

\section{Introduction}

The first report of the southern bottlenose whale, Hyperoodon planifrons (Flower, 1882) from Antarctic seas, or, indeed, from any part of the southern hemisphere, was made by Sir James Clark Ross (1847, vol. I, p. 167) who on 22 December 1840 in $59^{\circ} \mathrm{S} 171^{\circ} \mathrm{E}$ sighted 'a few bottlenosed whales'; at that time these were not recognised as a species separate from the northern bottlenose whale, Hyperoodon ampullatus (Forster, 1770). Recent reviews by Arvy and Pilleri (1983), International Whaling Commission (1989) and Mead (1989) show that the southern bottlenose whale is widely distributed in the southern hemisphere: it extends from the ice-edge northwards at least to $20^{\circ} \mathrm{S}$ in the Southeast Indian Ocean off Australia where the skull of the type was found (Flower, 1882), to $34^{\circ} \mathrm{S}$ in the Southwest Indian Ocean off South Africa (Tietz, 1966; Nemoto et al., 1980) and again to $34^{\circ} \mathrm{S}$ in the Southwest Atlantic off Brazil (Gianuca and Castello, 1976), and to $33^{\circ} \mathrm{S}$ in the Southeast Pacific off Chile (R. Clarke, 1962). The general distribution given by Ross et al. (1989, Figure 2, Tables 1 and 7) is incomplete. However, the headquarters of the species are the Antarctic seas where it is now reported to be abundant (Kasamatsu et al., 1988; Kasamatsu and Shigemune, 1989; Kasamatsu 1991; 1993; Ohsumi et al., 1995; Van Waerebeek et al. 2004).

Except for 42 animals taken by Soviet fleets in the Antarctic between 1970 and 1982 (Kasamatsu et al., 1988) there has never been a directed fishery for the southern bottlenose whale, and, although a number of sightings have been recorded (the validity of which will be discussed later), the whale is mostly known from stranded specimens, more or less decomposed. I know of only two publications on specimens of $H$. planifrons taken for scientific investigation, by Tomilin and Latyshev (1967) and by Zemski and Budylenko (1970); these papers are in Russian and I refer to them as cited by Arvy and Pilleri (1983) and Mead (1989). In fact, it seems that at the present day little more is known of the biology of $H$. planifrons than when, fifty seven years ago, a specimen was specially shot and worked up for me when I was the Whale Fishery Inspector on the expedition of Floating Factory Southern Harvester to the Antarctic in 1947-48, and when I was also conducting a research programme for the 'Discovery' Investigations of the British Colonial Office, which became part of the National Institute of Oceanography, later the Institute of Oceanographic Sciences. This whale, a lactating female $7.45 \mathrm{~m}$ long, is the main subject of the present report.

Apart from whatever the two Russian papers mentioned may contain, I summarize here the dissection by Dixon et al. (1994) of a young male H. planifrons stranded in Victoria, Australia on 22 September 1992. Morphometry is registered. After describing the body colour there are mentioned 'rudimentary mammary slits' where R. Clarke (2005) should be consulted. The stomach

${ }^{1}$ Apartado 40, PISCO, Perú. E-mail: robertclarke007@hotmail.com. 
compartments are briefly described, two being packed with 'marine organisms'. The cranium, mandibles and vertebrae are discussed at length. The blubber was submitted to organochlorine analysis. These results are not relevant to my description of the lactating female H. planifrons I examined in 1948. Van Waerebeek et al. (2004) summarized knowledge on $H$. planifrons including its distribution and its considerable abundance in Antarctic seas.

Circumstances have been such that it is only now that I have found time to prepare my material for publication.

\section{Material and Methods}

Between 23 and 26 November 1947 I sailed with Captain Johan Antonsen in the whalecatcher Satsa and saw altogether seven southern bottlenose whales in the Antarctic between $56^{\circ} 05^{\prime} \mathrm{E}$ and $55^{\circ} 40^{\prime} \mathrm{E}$. The behaviour of one of them is described in the next section.

Knowing that practically nothing was known of the southern bottlenose whale I asked the manager of the expedition, Captain Konrad Granøe, whether one of these whales could be shot and worked up for me during some slack time in the whaling. Captain Granøe kindly agreed and on 10 March 1948 the fangst-løder Captain T. Olsen sailing in w/c Southern Gem shot a female southern bottlenose whale measuring $7.45 \mathrm{~m}$. (24 ft $5 \mathrm{in}$ ). The factory ship was then far south from Tierra del Fuego in noon position $61^{\circ} 09^{\prime} \mathrm{S}, 86^{\circ} 44^{\prime} \mathrm{E}$. Captain Olsen used a harpoon without explosive charge so that minimum damage was done to the internal organs. The whale was hauled up and placed on one side of the afterplan, the flensing deck, where I worked on it all day. After examining the external characters and making appropriate measurements I requested that the whale be flensed and the skeleton dismembered. This was done whilst I examined the internal organs. A number of specimens were taken of these and also of parasites, preserved in $10 \%$ neutral seawater formol or Bouin's fluid. These specimens, labelled SH 159-170, should be available in the Discovery Collections, British Museum (Natural History), South Kensington, London. I roughly cleaned the flesh from the bones of the skeleton (specimen $\mathrm{SH}$ 172) and packed them in 14 sacks and two burlap packages (the skull and lower jaw). The sacks included the hyoid apparatus and the larynx and laryngeal cartilages. All were placed in the ship's refrigerator (meat cold room) and when they arrived in Liverpool they were transported by refrigerator van to the British Museum (Natural History) on 31 May 1948, where the skeleton is now available.

For two days after the southern bottlenose whale was shot only five sperm whales and one fin whale were taken. Several members of the crew blamed the taking of the bottlenose, denounced as a 'demon, ogre, a troll hval'. In the forenoon of 15 March three flensers and a lemmer scrubbed with hot caustic soda the claw which had heaved up the whale and the place where the whale had lain on the flensing deck. In the afternoon 14 fin whales were taken.

There follow the Results of this investigation.

\section{A SOUTHERN BOtTLENOSE WHALE AT SEA}

Of the seven bottlenose whales observed during my excursion in w/c Satsa in November 1947 only two were seen together at any one time. On 26 November I photographed one steering a southerly course at 4-5 knots (Figure 1). The spout had a wide, bushy top and was not inclined. The whale sounded for 12-14 minutes and then blew three times at intervals of 15 seconds. The sounding time is near the minimum time of 11 minutes given by Kasamatsu (1993) whose average and maximum times were 25.3 and 46 minutes respectively for beaked whales in the Antarctic. It dived in a shallow area and did not show its flukes, which accords with Sapin-Jaloustre's observation (1953). However, Gray (1882) said that the northern bottlenose whale can breach and takes the water clean, whilst Mead (1989, Figure 6) says that the northern bottlenose whale does sometimes show its flukes when diving. The dorsal fin of our whale was of medium size, falcate, and placed far back. The body colour was a fairly uniform brownish-yellow but as will be seen (p.86) this could have been partly due to diatom film. On the flank anterior to the dorsal fin I glimpsed a cross-hatching of white scars and their origin will be discussed later.

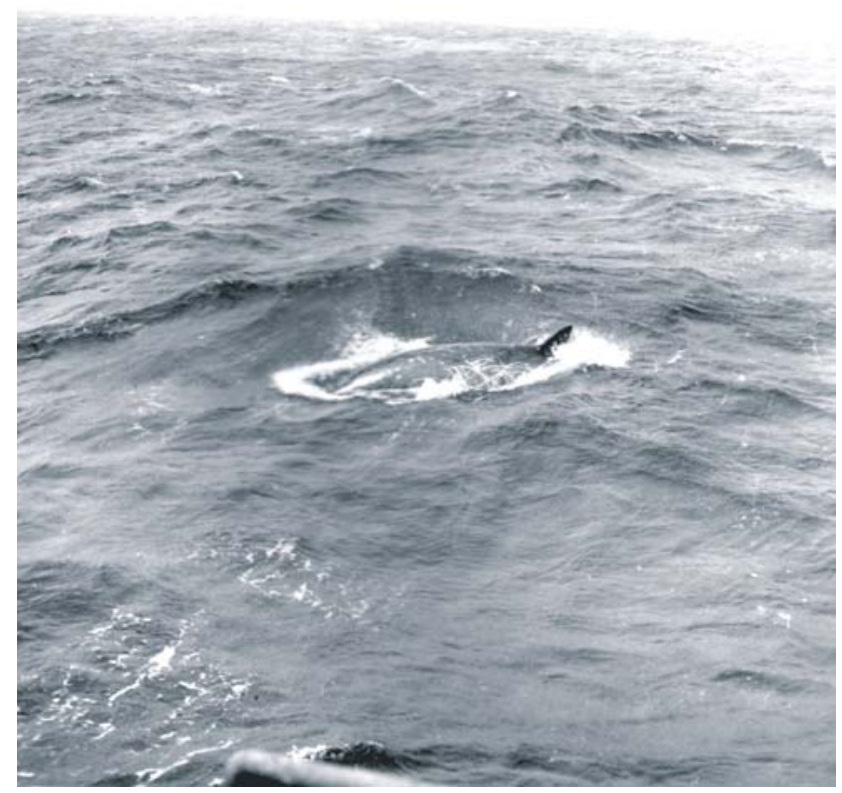

Figure 1. A southern bottlenose whale at sea on 26 November 1947. (Photo: Robert Clarke). 
THE WHALE EXAMINED ON 10 MARCH 1948

\section{Morphometry}

Arvy and Pilleri (1983) say that the southern bottlenose is larger than the northern bottlenose. But this may not be so. Fraser (1964) considered that the total length of the present specimen of $H$. planifrons, $7.45 \mathrm{~m}$, is the maximum reported size for a female of this species whereas Fischer (1881) examined a female of $H$. ampullatus of $7.72 \mathrm{~m}$. In any case sightings of $H$. planifrons as large as $12 \mathrm{~m}$ (Racovitza, 1903) and $15 \mathrm{~m}$ (Liouville, 1913) are surely not acceptable.

Table 1 shows the body proportions of the present female specimen of $H$. planifrons from the Antarctic. Wherever comparable there are included proportions of two female H. ampullatus, Fischer's specimen of $7.72 \mathrm{~m}$ and another of 7.20 m examined by Bouvier (1892). Fischer's proportions are reproduced by Arvy and Pilleri (1983, Table V).

Table 1. Body proportions of the female H. planifrons from the Antarctic and comparable proportions of female H. ampullatus described by Fischer (1881) and Bouvier (1892).

\begin{tabular}{|c|c|c|c|c|c|c|}
\hline \multirow[t]{3}{*}{ MEASUREMENTS } & \multirow{2}{*}{\multicolumn{2}{|c|}{$\begin{array}{c}\text { H. planifrons } \\
\text { PRESENT SPECIMEN }\end{array}$}} & \multicolumn{4}{|c|}{ H. ampullatus } \\
\hline & & & \multicolumn{2}{|c|}{ FISCHER (1881) } & \multicolumn{2}{|c|}{ BOUVIER (1892) } \\
\hline & METRES & PERCENT & METRES & PERCENT & METRES & PERCENT \\
\hline Total length & 7.45 & 100.0 & 7.72 & 100.0 & 7.20 & 100.0 \\
\hline Length of snout & 0.65 & 8.7 & & & & \\
\hline Projection of snout beyond tip of lower jaw & 0.03 & 0.4 & & & & \\
\hline Tip of snout to blowhole & 0.96 & 12.9 & 1.30 & 16.6 & & \\
\hline Tip of snout to angle of gape & 0.53 & 7.1 & & & & \\
\hline Tip of snout to centre of eye & 0.94 & 12.6 & & & 1.14 & 16.0 \\
\hline Tip of snout to tip of flipper & 2.38 & 33.4 & & & & \\
\hline Centre of eye to centre of ear & 0.02 & 2.6 & & & & \\
\hline Posterior margin of dorsal fin to end of flukes & 2.33 & 32.6 & $2.71^{\mathrm{i}}$ & 35.2 & 2.20 & 30.6 \\
\hline Width of flukes at insertion & 0.23 & 3.2 & & & 0.22 & 3.1 \\
\hline Span of flukes, tip to tip & 2.11 & 28.3 & 2.21 & 28.6 & 2.00 & 26.4 \\
\hline Length of flukes in mid-line & 0.65 & 8.7 & & & & \\
\hline End of flukes to anus & 1.98 & 26.6 & & & & \\
\hline End of flukes to umbilicus & 3.74 & 50.2 & & & & \\
\hline Centre of anus to centre of vulva & 0.20 & 2.7 & & & & \\
\hline Height of dorsal fin & 0.41 & 5.5 & 0.40 & 5.2 & & \\
\hline Length of dorsal fin & 0.53 & 7.1 & 0.64 & 8.4 & & \\
\hline Tip of flipper to axilla & 0.71 & 9.5 & 0.64 & 8.4 & & \\
\hline Tip of flipper to anterior end of lower border & 0.91 & 12.2 & & & 0.80 & 11.1 \\
\hline Length of flipper along curve of lower border & 0.92 & 12.4 & & & & \\
\hline Greatest width of flipper & 0.24 & 3.3 & & & & \\
\hline Depth of tail at dorsal fin & 1.31 & 17.6 & & & & \\
\hline Length of left throat groove & 0.46 & 6.2 & & & 0.40 & 5.6 \\
\hline Length of right throat groove & 0.41 & 5.5 & & & 0.40 & 5.6 \\
\hline Anterior separation of throat grooves & 0.05 & 0.7 & & & 0.09 & 1.3 \\
\hline Posterior separation of throat grooves & 0.38 & 5.1 & & & 0.32 & 4.6 \\
\hline Greatest width of throat grooves & 0.03 & 0.4 & & & & \\
\hline Width of the blowhole slit & 0.18 & 2.4 & & & 0.20 & 2.8 \\
\hline Length of the vulva along major lips & 0.59 & 7.9 & & & 0.56 & 7.8 \\
\hline Length of the teat grooves & 0.09 & 1.2 & & & 0.10 & 1.4 \\
\hline Length of the larger ovary & 0.128 & 1.7 & & & 0.10 & 1.4 \\
\hline Length of the mammary glands & 1.40 & 18.8 & & & 1.15 & 16.0 \\
\hline Breadth & 0.17 & 2.3 & & & 0.22 & 3.1 \\
\hline Thickness & 0.07 & 0.9 & & & 0.04 & 0.6 \\
\hline Length of skull, condyle to tip of premaxillai & 1.49 & 20.0 & & & & \\
\hline Greatest width of skullii & 0.76 & 12.0 & & & & \\
\hline Length of disarticulated lower jaw ${ }^{\mathrm{ii}}$ & 1.22 & 16.4 & & & & \\
\hline Length of the small intestine & 23.30 & 312.8 & & & 28.50 & 395.8 \\
\hline Width of the small intestine & $0.05-0.06$ & $0.7-0.9$ & & & & \\
\hline
\end{tabular}

${ }^{i}$ Fischer has 'Du rostre à la dorsale $4.37 \mathrm{~m}$ '. By adding his 'Longeur de la dorsale é sa base $0.64 \mathrm{~m}$ ' and then subtracting from the total length, $7.72 \mathrm{~m}$, we obtain the posterior margin of dorsal fin to end of flukes, $2.71 \mathrm{~m}$. ii The skull was measured when it had only been roughly cleaned. 
Comparing the present specimen with the two northern bottlenose whales, the only measurement which shows a substantial difference is the length of the small intestine, and this could be due to differences or difficulties in unravelling the intestine. Otherwise it is noteworthy that the remaining 14 proportions that may be compared are very similar in $H$. planifrons and $H$. ampullatus and the small differences may be attributed to individual variation or to where the limits of an organ (e.g. the dorsal fin) are a subjective decision. Then, on present data, and at least in the female, there appear to be no substantial differences in morphometry between the two species.

\section{External characters}

The background colour of the body was a dull yellowish-brown which was uniform all over the whale except for a somewhat lighter tone along the flanks. Diatom film (p.84, 92) which occurs on whales which have been at least a month in Antarctic waters (Hart, 1935) may have contributed to the background colour. Roughly circular unpigmented areas, between one and four $\mathrm{cm}$ in diameter, occurred towards the flanks and increased in number ventrally, being most numerous on the ventral surface. These white spots were augmented by the white colour of oval scars (p.92) which were fairly liberally scattered over the body surface. In the umbilical region a faint streaking of the pigment appeared as a slight whirl around the umbilicus. Below the angle of gape the lower jaw was paler than the remainder of the head. Figures 2 and 3 illustrate most of this description.

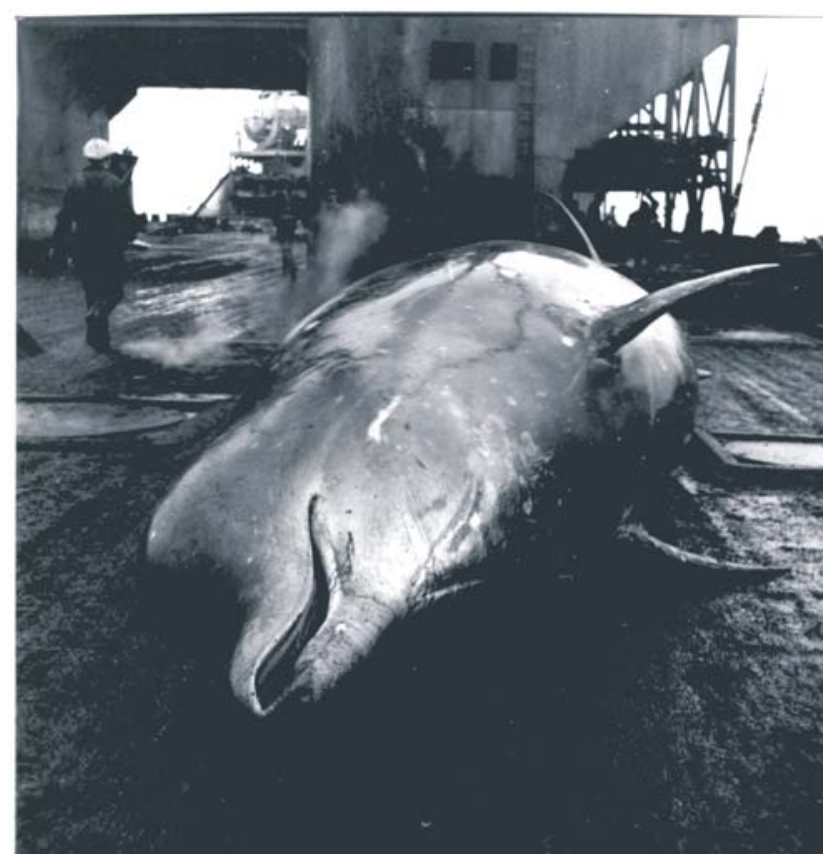

Figure 2. Anterior view of the southern bottlenose whale examined on 10 March 1948. (Photo: Robert Clarke).
Mead (1989) has reviewed what is known of the body colour of northern and southern bottlenose whales and he mentions several workers who consider that juveniles and adults of the two species do not differ much in this respect. I am in agreement, at least so far as females are concerned, mentioning only that the masking effect of the diatom film seems not to be found in bottlenose whales of far northern latitudes. However, Van Waerebeek et al. (2005) have shown that juveniles of the southern bottlenose whale do differ from the adults in body colouration.

Some long scratches, healed and white in colour occurred on the flanks and belly of this specimen; most of them were in an area one third of the distance between the flippers and the vulva and were transverse or lateraltransverse in position. One of these was $2.1 \mathrm{~m}$ long and extended from about $0.2 \mathrm{~m}$ behind the insertion of the flipper to about $0.5 \mathrm{~m}$ behind the umbilicus. It commenced as six well-defined parallel lacerations, each about $4 \mathrm{~cm}$ long and spaced more or less equidistant from each other at intervals of $2.5 \mathrm{~cm}$ and extending altogether across $14 \mathrm{~cm}$. These lines then became thinner, converging and intercrossing as they extended posteriorly. This scratch was crossed by another at 0.67 $\mathrm{m}$ from its origin; the second scratch was $1.2 \mathrm{~m}$ long. Similar scratches, showing groups of parallel short lines, occurred as a group of eight behind the throat grooves and as a group of ten on the outer surface of the right flipper. In the genital region there were only three scratches, about $0.3 \mathrm{~m}$ long, and faint and obviously old. On the region posterior to the right flipper there were a few sickle-shaped or hook-shaped scars.

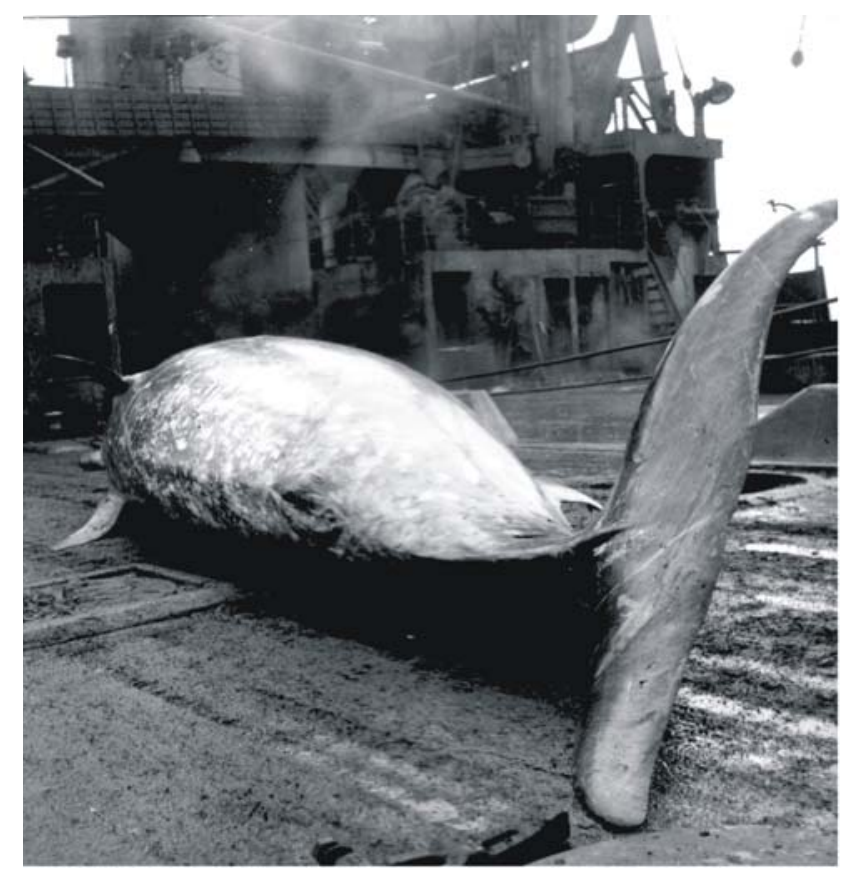

Figure 3. Postero-lateral view of the whale examined on 10 March 1948. (Photo: Robert Clarke). 
Parallel scratches like those described were observed by Scheffer (1969) on the flank of a killer whale Orcinus orca and he believed that they were made by the teeth of another killer whale. Now, although there is good evidence for intraspecific fighting in the sperm whale (R.Clarke and Paliza, 1988), I consider that the long scratches on this present specimen of the southern bottlenose whale were caused by the denticulate suckers on the arms and tentacles of squids. Wilson (1907) also believed that the 'white hieroglyphic markings' on bottlenose whales in the Antarctic were caused by squid. Mead (1989) however believes that 'the white scars on ziphiids... cannot be attributed to a single cause'.

The snout projected slightly beyond the tip of the lower jaw (Figure 2, Table 1). Now Table 2, partially compiled from my observation, shows that there is no consistency about this feature in either $H$. planifrons or H. ampullatus. The snout can project beyond the tip of the lower jaw, or vice-versa, or there is no projection. Individual variation, careless drawing of figures or sexual dimorphism may be involved, but the matter certainly calls for further investigation.

The flippers (Table 1, Figure 2) were placed fairly low down, and were moderately slender and pointed. They were a uniform yellowish-brown colour on both surfaces.

The dorsal fin (Table 1, Figure 1) was placed far back, falcate and rather high.

The broad flukes (Table 1, Figure 3) as in the northern bottlenose and in other ziphiids, had no notch in the center line; in fact, there was a slight protuberance.
The blowhole (Table 1) was placed transversally across the top of the head in the centre-line as a symmetrical bow-shaped slit, $18 \mathrm{~cm}$ long, with the concavity of the bow facing forwards. This was how Bouvier (1892) saw it in $H$. ampullatus, and the length of the blowhole in females of the two species was proportionately about the same (Table 1).

Each external ear (meatus) was a minute, precisely circular opening, $1.5 \mathrm{~mm}$ in diameter, flush with the skin surface and lying about one third of the distance between the eye and the insertion of the flipper (Table 1).

One of the eyes was removed during flensing. It was 4.5 $\mathrm{cm}$ from front to back, $6.8 \mathrm{~cm}$ high and $7.3 \mathrm{~cm}$ broad. It weighed 150 grams. The pupil measured $1.3 \mathrm{~cm}$ from front to back and was $1.7 \mathrm{~cm}$ broad. The eyes were comparatively larger than those of a sperm whale. Thus a sperm whale examined on this expedition as Whale $\mathrm{SH}$ 397 on 6 January 1947, measuring $14.9 \mathrm{~m}$ and twice the size of the present bottlenose, had eyes measuring 4.2 $\mathrm{cm}$ by $6.8 \mathrm{~cm}$ by $6.5 \mathrm{~cm}$, just about the same dimensions as those of the present specimen of Hyperoodon.

Although the presence of rough papillae on the palate has been considered a characteristic of the genus, as indicated in the generic name Hyperoodon, the palate of the present specimen was smooth (Figure 4. A hook is slung over the mandible). It was a dark, greenish colour anteriorly, becoming dirty pink in the region of the gape. The floor of the mouth had the same colouring as the palate. The tongue was short, broad and firm, much resembling that of a sperm whale; it was yellowish in colour, suffused with pink.

Table 2. Hyperoodon. Projection of the snout beyond the tip of the the lower jaw, vice-versa, or no projection.

\begin{tabular}{|c|c|c|c|c|c|}
\hline \multicolumn{3}{|c|}{ Hyperoodon planifrons } & \multicolumn{3}{|c|}{ Hyperoodon ampullatus } \\
\hline REFERENCE & AUTHORITY & OBSERVATION & REFERENCE & AUTHORITY & OBSERVATION \\
\hline $\begin{array}{l}\text { Arvy \& Pilleri } \\
\text { 1983, Fig.37 }\end{array}$ & Hale, 1931 & No projection & $\begin{array}{l}\text { Arvy \& Pilleri } \\
\text { 1983, Fig.2 }\end{array}$ & Dale, 1730 & $\begin{array}{l}\text { Snout projects } \\
\text { beyond lower jaw }\end{array}$ \\
\hline Fraser, 1945, p.35 & $\begin{array}{l}\text { Harrison } \\
\text { Matthews, } 1927 . \\
\text { MS from S. } \\
\text { Georgia }\end{array}$ & $\sigma^{\prime}$. No projection & $\begin{array}{l}\text { Do, Fig. } 3 \\
\text { Jacob, } 1825\end{array}$ & $\begin{array}{l}\text { Bassaud, } 1789 \\
\text { Jacob, } 1825\end{array}$ & $\begin{array}{l}\text { ㅇ․ No projection } \\
\sigma . \text { Snout projects } \\
\text { beyond lower jaw }\end{array}$ \\
\hline \multirow[t]{3}{*}{ Tietz, 1966} & Tietz, 1966 & $\begin{array}{l}\sigma^{\prime} . \text { Lower jaw } \\
\text { projects beyond } \\
\text { snout in his Fig.1, }\end{array}$ & $\begin{array}{l}\text { Arvy \& Pilleri, } \\
\text { 1983, Fig.5 }\end{array}$ & $\begin{array}{l}\text { Eudes-Deslong } \\
\text { champs, } 1842\end{array}$ & $\sigma^{\prime \prime}$. No projection \\
\hline & & $\begin{array}{l}\text { but he says (p.103) } \\
\text { that the lower jaw } \\
\text { does not project }\end{array}$ & Turner, 1886 & Turner, 1886 & $\begin{array}{l}\text { o. Lower jaw projects } \\
\text { beyond snout. }\end{array}$ \\
\hline & & beyond snout. & $\begin{array}{l}\text { Arvy \& Pilleri, } \\
\text { 1983, Fig.16 }\end{array}$ & Gray, 1882 & $\begin{array}{l}\text { Q . Snout appears to } \\
\text { project beyond lower } \\
\text { jaw }\end{array}$ \\
\hline \multirow[t]{2}{*}{ Present paper } & $\begin{array}{l}\text { Present paper, } \\
\text { Tab.1, Fig.3 }\end{array}$ & $\begin{array}{l}\text { 9. Snout projects } \\
\text { beyond lower jaw }\end{array}$ & $\begin{array}{l}\text { Mead, 1989, } \\
\text { Fig.3 }\end{array}$ & Gray, 1882 & $\begin{array}{l}\text { ㅇ and } 40^{\circ} \text {. Lower } \\
\text { jaw projects slightly } \\
\text { beyond snout }\end{array}$ \\
\hline & & & $\begin{array}{l}\text { Arvy \& Pilleri, } \\
\text { 1983, Fig.15 }\end{array}$ & Ohlin, 1893 & $\begin{array}{l}\text { ठ". Lower jaw projects } \\
\text { beyond snout. }\end{array}$ \\
\hline
\end{tabular}




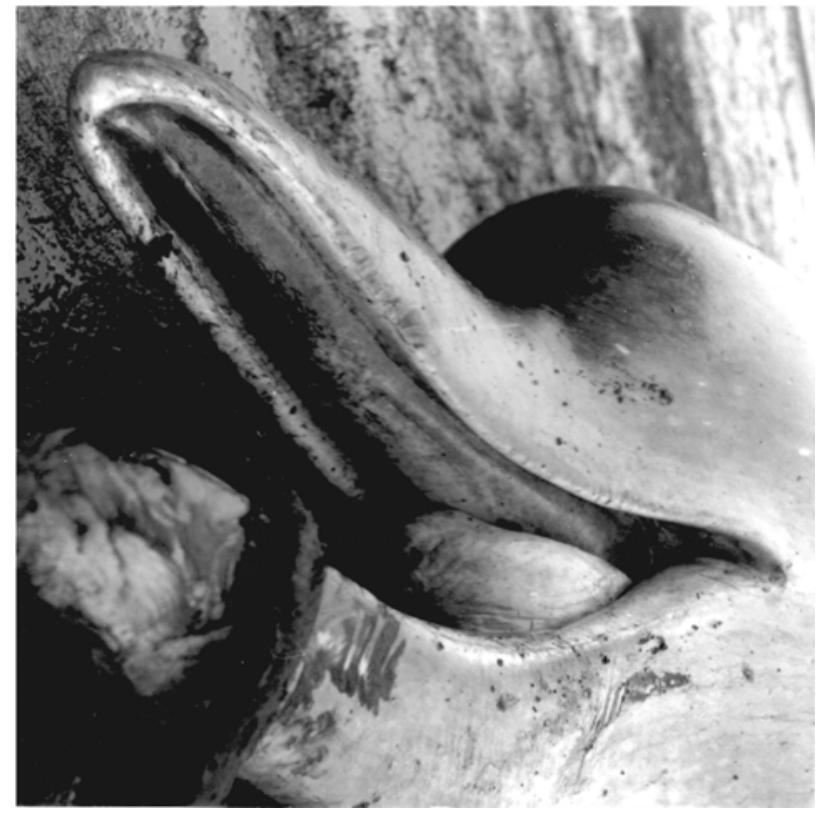

Figure 4. Mouth of the whale examined on 10 March 1948. (Photo: Robert Clarke).

The larynx appeared large for the size of the animal and the arytaenoid cartilages were not fused into an indented ring as in the sperm whale but were free and projected similar to the flap-like arytaenoids of whalebone whales. The larynx was packed with the skeleton because I had learned from Beddard (1900, p.227) that ziphioid whales were said to have a distinct voice and that a northern bottlenose had been heard to 'sob', Mead (1989, p.341) refers to a paper by Hale (1939), which I have not seen, where a stranded male $H$. planifrons was recorded as having made 'a grunting noise like a pig, with an occasional squeal'. I do not know whether the larynx of the present specimen was ever examined but in any case it is now recognized that the larynx of Odontocetes contains no vocal chords and that sound is produced from the nasal sacs.

The head and beak were carefully searched for hairs, but none were present. Beddard mentioned that W.Kükenthal thought he saw hairs on the snout of $H$. ampullatus but a histological study could not confirm this.

The throat grooves (Table 1, Figure 2) diverged posteriorly as indicated in Table 1 . They were of a purplish red colour. Throat grooves, present in all ziphiid whales, had the same proportions in the present specimen as in Bouviers' female of H. ampullatus (1892). The two unerupted teeth in the lower jaw of the present specimen are considered below.

The anus was a transverse slit, $4.5 \mathrm{~cm}$ long, situated immediately behind the vulva which was swollen and congested, of a deep reddish-pink colour (Figure 5). Anus and vulva together measured $0.59 \mathrm{~m}$. There were indications that in the resting condition the vulva and anus would be included in a shallow cloaca as in the female sperm whale.

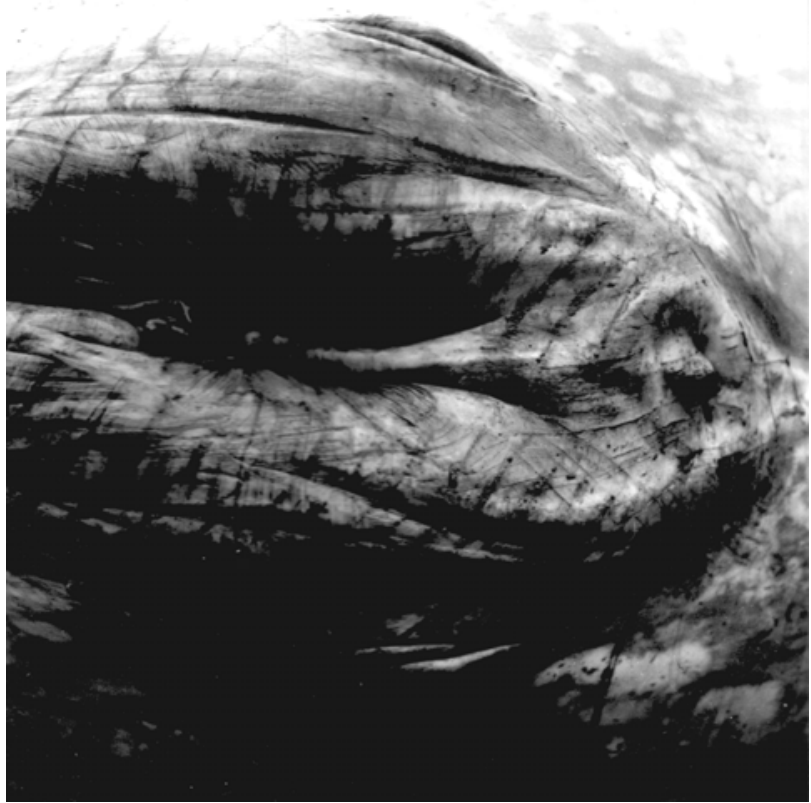

Figure 5. Vulva and anus of the whale examined on 10 March 1948. (Photo: Robert Clarke).

The blubber had a pinkish tinge like that often seen in sperm whales, but more pronounced. It was $6 \mathrm{~cm}$ thick at a point $15 \mathrm{~cm}$ below the dorsal fin. This gives a fatness relative to body length of $0.81 \%$, precisely the same as the aggregate result for the relative fatness at the flank of lactating sperm whales from the Southeast Pacific ( $R$. Clarke, et al.1988, p.71). A limpid oil oozed from the fatty tissue occupying the shallow hollow on the inner side of each mandible. A sample of this jaw oil was collected as sample SH 160. There was also a small oil reservoir in the head, below and in front of the maxillary crests.

Arvy and Pilleri (1983, p.40) compare in their Table VI physical characters of the spermaceti from the head of the northern bottlenose whale with those of spermaceti from the sperm whale: they say that the spermacetis are not identical. No, but they are very similar, and I would expect spermaceti from the southern bottlenose to share this close similarity.

\section{Teeth and age}

As in the female of the northern bottlenose whale the present specimen had two unerupted teeth in the front of the lower jaw. I did not attempt to remove these when packing the skeleton. However one of these teeth was examined, along with those of the northern species and of other ziphiids, at the International Conference on determining Age of Odontocete Cetaceans and Sirenians at La Jolla, California, September 5-19, 1978. The tooth from the present specimen was structurally very similar to those of $H$. ampullatus. The count of the growth layer groups (GLG's) in the cement was 26 and was considered probably more reliable than the count of 20 in the dentine (Perrin and Myrick - Eds, 1980, p.5). 
So, if one GLG represents one year in the southern bottlenose whale as in most odontocetes, the present specimen was 20-26 years old. I had no opportunity to examine the condition of fusion of epiphyses to centra in the axial skeleton before packing the bones, but it seems likely that at this age the whale was probably physically mature; Christensen (1973) concluded that the female $H$. ampullatus seemed to achieve physical maturity at about $7.5 \mathrm{~m}$ and somewhat earlier than 20 years of age.

\section{Digestive system}

Since the many-chambered stomachs of ziphiid whales have aroused much interest in the past I examined the stomach of the present specimen in some detail, cutting it out and dissecting it as it lay upon the flensing deck.

Externally the stomach appeared as a fairly compact organ, $115 \mathrm{~cm}$ in overall length and showing a partial constriction making two large sacs of roughly equal size (Figure 6A). The first of these, which externally had an additional transverse fold across part of its surface, had a maximum breadth of $48 \mathrm{~cm}$. The second sac was $64 \mathrm{~cm}$ broad and the slight constriction demarcating the two measured $38 \mathrm{~cm}$ across. The greatest collapsed depth of the organ was about $24 \mathrm{~cm}$. When writing up my notes on board the Southern Harvester I called the first sac, which was a single large chamber, the 'True Stomach' in contrast to the manychambered second sac, which I called the 'Multiloculate Stomach'. I retain these terms here as being more expressive than the corresponding 'cardiac stomach' and 'pyloric stomach' which were used by investigators of $H$. ampullatus in the nineteenth century. The two sacs are described in turn.

\section{Hyperoodon sp.}

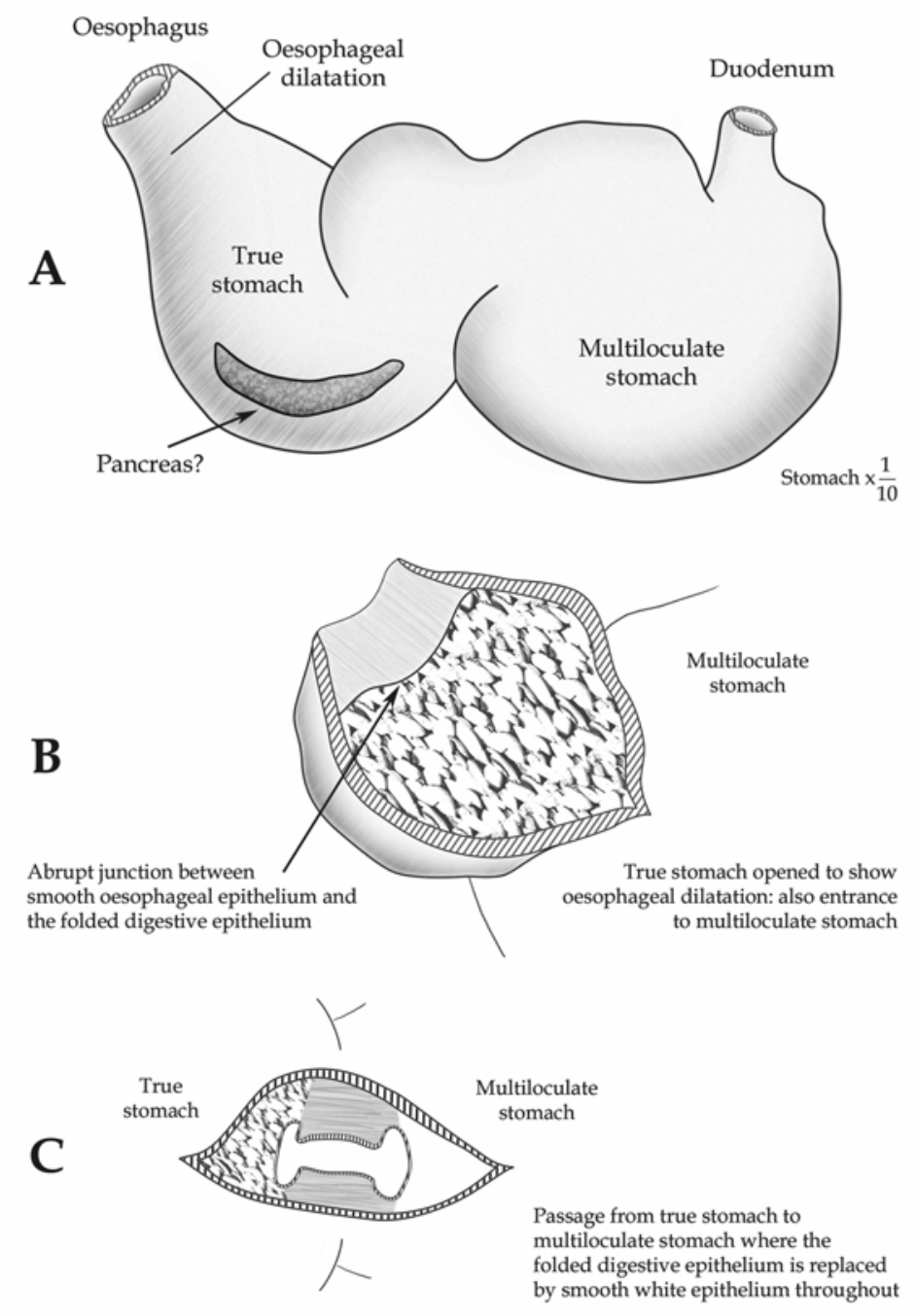

Figure 6. The stomach of the whale examined on 10 March 1948. The complete stomach. (A) The true stomach opened., (B) the passage leading from the true stomach to the first chamber of the multiloculate stomach. (Photocopy of sketches made by Robert Clarke on 11 March 1948). 
Slung by a fold of mesentery against the wall of the true stomach, there lay the compact, crescentic pancreas, a dark brown body, $32 \mathrm{~cm}$ long, $12 \mathrm{~cm}$ wide and $4 \mathrm{~cm}$ deep. I regret that the path of the pancreatic duct, and also that of the bile duct, into the duodenal region were not traced out. I had left this matter until the main examination of the stomachs was completed, but at this stage, and whilst I had briefly left the deck, the stomach mass became lost under tons of fin whale blubber.

The true stomach had thick muscular walls $4.5 \mathrm{~cm}$ thick, and the single cavity was lined by a grayish-brown digestive epithelium thrown into reticulating folds; a sample was fixed in Bouin's fluid as specimen SH 167. The end of the oesophagus measured $7 \mathrm{~cm}$ in collapsed diameter and the smooth yellowish-white oesophageal epithelium was continued into the commencing dilatation of the stomach for a distance of $15 \mathrm{~cm}$. The junction of this smooth epithelium with the folded mucous one was strikingly abrupt, as though the oesophageal lining were a sheet of thick vellum glued upon the larger folded lining (Figure 6B and Figure 7). I consider that this oesophageal dilatation in the cardiac end of the true stomach corresponds to the first non-digestive or holding stomach of whales and dolphins other than the Ziphiidae. Jungklans (recorded by Beddard, 1900, p.63) observed a 'slight, caecal dilatation of the oesophagus' in $H$. ampullatus, although in the present specimen of $H$. planifrons the dilatation was not caecal.

Opposite the cardiac end of the first or true stomach a passage, $9.0 \mathrm{~cm}$ in collapsed diameter and $12.5 \mathrm{~cm}$ long, led into the first chamber of the multiloculate stomach (Figure 6C). The lining of this passage, and of all the chambers and passage ways of this second sac, was a uniform smooth white ephitelium which did not appear

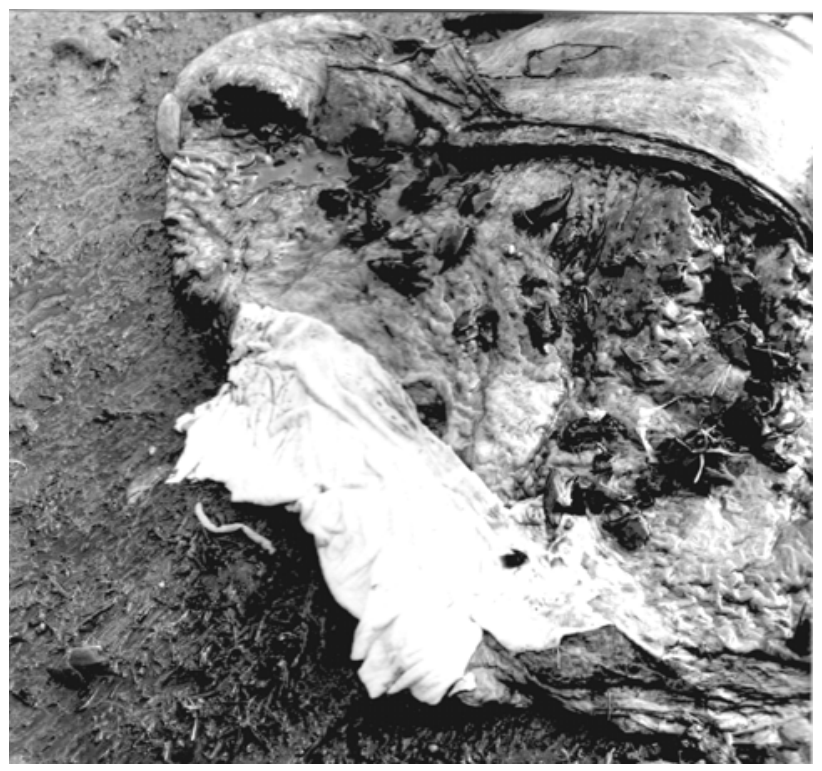

Figure 7. The true stomach opened to show its junction with the oesophageal dilation. (Photo: Robert Clarke). to be digestive; a sample was fixed in Bouin's fluid as specimen SH 168. The dividing walls of the various chambers were muscular and about $2 \mathrm{~cm}$ thick except for the external wall which was slightly thicker at 2 to 3 $\mathrm{cm}$, especially around the last (sixth) chamber.

The multiloculate stomach was so compact that the six intercommunicating chambers appeared as though excavated out of the substance of the organ. The entrance and exit of each chamber were invariably at right angles and not always in the same plane, so that the third chamber lay above the fourth in the thickness of the sac, and the sixth and largest chamber overlapped the fifth (Figure 8).

Whilst tracing out these rounded cavities of the multiloculate stomach an attempt was made to estimate the volume of each in the collapsed condition by measuring three dimensions at right angles whilst holding the walls part. This gives an overestimation so that the 'ovoid volume formula' is now applied, $4 / 3 \mathrm{x}$ pi $\times(\mathrm{L} \times \mathrm{W} \times \mathrm{D} / 8)$.

\begin{tabular}{|l|c|c|}
\hline \multirow{2}{*}{ First chamber } & $\mathrm{L} \times \mathrm{W} \times \mathrm{D}$ & $\begin{array}{c}\text { Ovoid volume } \\
\text { formula applied }\end{array}$ \\
\cline { 2 - 3 } Second & $35 \times 16 \times 11 \mathrm{~cm}=6.21$. & 3.221. \\
& $25 \times 16 \times 13 \mathrm{~cm}=5.21$. & 2.721. \\
Third & $18 \times 11 \times 9 \mathrm{~cm}=1.81 \mathrm{l}$. & 0.931. \\
Fourth & $20 \times 13 \times 9 \mathrm{~cm}=2.31$. & 1.221. \\
Fifth & $33 \times 30 \times 13 \mathrm{~cm}=12.91$. & 6.741. \\
Sixth & $33 \times 30 \times 23 \mathrm{~cm}=22.81$. & 11.921. \\
\hline \multicolumn{2}{|c|}{ Total capacity of the multiloculate stomach $=51.21}$. & 26.751. \\
\hline
\end{tabular}

So the total estimated volume of the multiloculate stomach was 26.751 .

The duodenal exit of the sixth chamber (being the seventh compartment proper of the complete stomach) measured $5.0 \mathrm{~cm}$ in collapsed diameter. A sample of the intestine in this region was fixed in Bouin's fluid as specimen SH 169. The whole length of the small intestine was characterised by pronounced reticulate folding of the lining epithelium; to illustrate this a small section of the intestine was preserved in sea-water formalin as specimen $\mathrm{SH}$ 170. The intestine was unravelled and stretched along the flensing deck where it measured 23.3 $\mathrm{m}$ with diameter 5-6 cm (Table 1). This length was about three times the body length so that the intestine was in accordance with Fraser's observation (1937, p. 273) that 'the intestine [in $H$. ampullatus] makes up for its shortness by the elaborate reticulated folding into which the internal lining is thrown'.

Since, as I believe, 'the true stomach' or first compartment was the only one with a digestive epithelium, it is difficult to understand the function of the multiloculate stomach, either in the present specimen, or in the ziphiid whales generally, since all have a similar arrangement of multiple chambers. Possibly the food, permeated with gastric juice from the first compartment is broken up by muscular contractions of the walls as it passes through the chambers 
of the multiloculate stomach. Certainly, as will be seen, these chambers contained only squid beaks and eyelenses and no flesh. But the first chamber had even thicker and more muscular walls and so probably also had a trituratory function.

The stomach which most closely resembles that of the present specimen was figured for $H$. ampullatus by Vrolik (1848), reproduced by Arvy and Pilleri in their Fig. 26. Bouvier (1892, Plate 7, Figure 2) showed the stomach of $H$. ampullatus as a string of chambers (also reproduced by Arvy and Pilleri in their Figure 6), but this was the result of what must have been a laborious dissection for the stomach is actually a compact organ (Figure 6A).

In the present specimen of $H$. planifrons the true stomach and the multiloculate stomach comprised together seven chambers. Hunter (1787), Vrolik (1848) and Turner (1889) also counted seven chambers in their specimens of $H$. ampullatus. But Jacob (1825), Eschrict (1849) and Weber (1886) counted nine chambers and Eudes-Deslongchamps (1842) got eight or nine. Bouvier (1892, p.279) counted ten chambers in his specimen and he found it difficult to believe that such differences in the counts could be due to individual variation in an organ like the stomach. I agree with him. He asked whether the different counts might be due to incomplete dissection and went on to say that with more specimens subjected to this very delicate dissection the divergences might be considerably reduced. However I am certain that in the present specimen of $H$. planifrons there were only seven chambers.

\section{Hyperoodon sp.}

The six chambers of the multiloculate stomach (Semidiagrammatic)

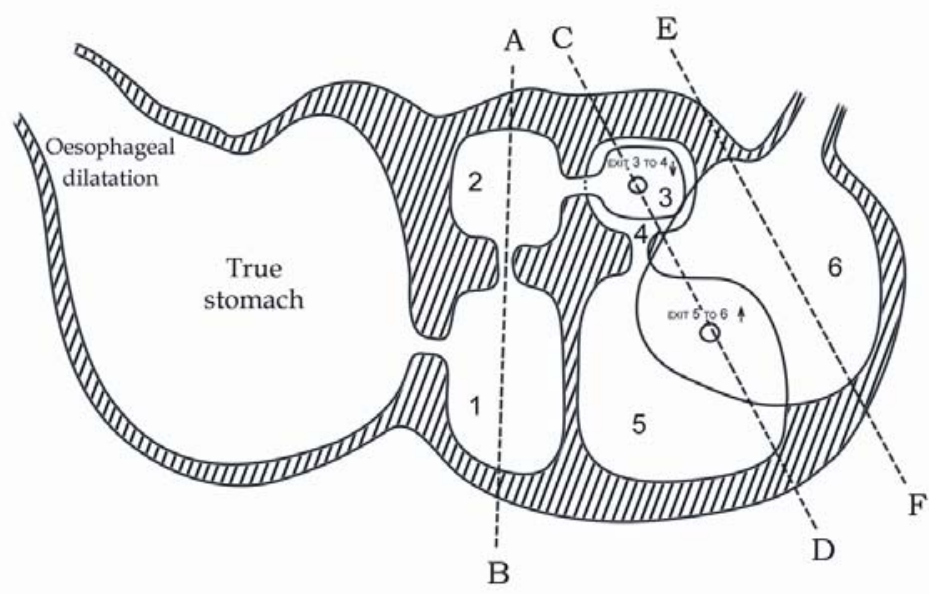

Multiloculate stomach (Semidiagrammatic sections)
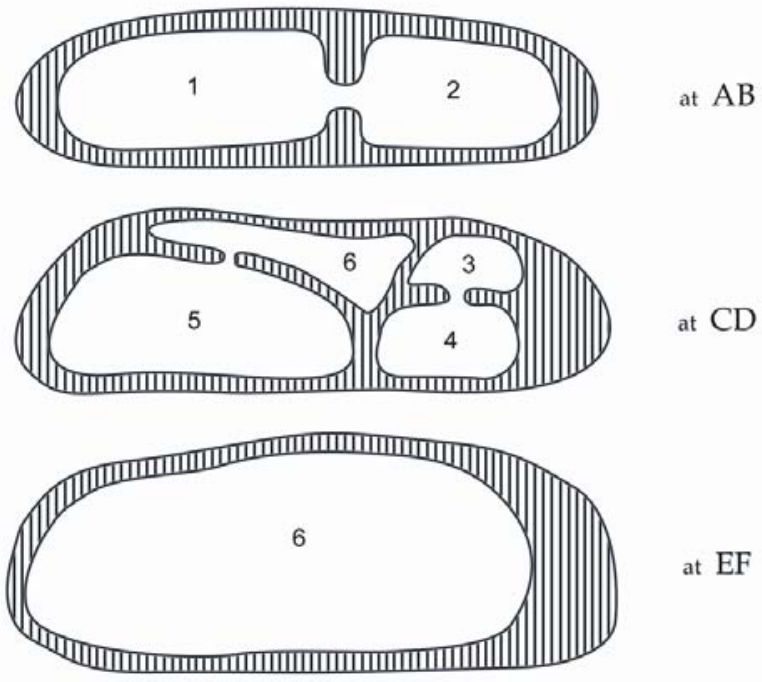

Figure 8. The multiloculate stomach (Photocopy of sketches made by Robert Clarke on 11 March 1948). 


\section{Stomach contents}

The stomach contents of the present specimen contained only a sparse to moderate amount of food. There were the backbone of an unidentified teleost fish measuring $25 \mathrm{~cm}$ with some flesh attached and the half-digested remains of six small squid; the head-and-arms of one of these only measured $15 \mathrm{~cm}$. There were a fair number of squid beaks and eye lenses and many squid spermatophores (Figure 7). The first chamber of the multiloculate stomach contained a squid pen (gladius), some beaks and eye-lenses and spermatophores, the second a few beaks and eye-lenses, the third a single beak, the fourth was empty, the fifth half full, say six or seven litres of beaks, eye-lenses and spermatophores, the sixth chamber was empty.

I did not collect the squid beaks because this whale was examined many years before M.R. Clarke published his papers on the identification of cephalopods from their beaks (1962, a and b). Squid beaks have also been reported from H. planifrons stranded in South Australia (Hale, 1931) and in Tierra del Fuego (Goodall and Galeazzi, 1985); a specimen from South Georgia contained only squid eyelenses (Fraser, 1945, p.35) but a southern bottlenose examined on board Floating Factory Balaena in 1956/57 contained some krill (Euphausia superba) as well as squid beaks (Ash, 1962, p.57). The beaks have now been identified from two specimens of $H$. planifrons examined on the east and west coasts of South Africa : oceanic squid from 36 species in 14 families have been identified (Sekiguchi et al., 1993). The northern bottlenose whale also feeds mainly on squid and Gonatus fabricii seems to be the principal species; fish are also sometimes taken, but occasional records of sea cucumbers, starfish, deep water prawns and stones and mud indicate that $H$. ampullatus must sometimes feed on the ocean floor (Benjaminsen and Christensen, 1979, p.154).

\section{Reproductive system}

The present specimen was lactating and probably advanced in lactation because when Captain Hansen shot the whale it was accompanied by another of a blackish colour which seemed very big for a calf.

The vulva had thick, fleshy lips. The clitoris was a conical incurving projection on its anterior margin. The urethra opened at the base of the clitoris and immediately posterior to it. There was no sign of the vaginal tag occasionally found in mature fin whales (Figure 5).

The ovaries were smooth compact organs. The right ovary weighed 100 grams and was $12.8 \mathrm{~cm}$ long, $5.6 \mathrm{~cm}$ wide and $1.6 \mathrm{~cm}$ deep. Some developing follicles were visible. A rounded protrusion on the dorsal surface, near to the ovarian ligament, was presumably the regressing corpus luteum of pregnancy; it measured $1.3 \mathrm{~cm}$ in diameter. Nearby there was a small, stalked body 0.8 $\mathrm{cm}$ in diameter. The left ovary weighed 61 grams and measured $9.8 \mathrm{~cm}$ in length, $6.2 \mathrm{~cm}$ in width and $1.6 \mathrm{~cm}$ in depth. Follicles were present but fewer than in the right ovary. I had in mind to postpone the sectioning of the ovaries until my arrival in London, and so they were preserved in seawater formalin as specimen SH 164. Unfortunately the ovaries were never sectioned for the count of corpora albicantia might have given a clue to the sexual cycle: however, these ovaries should be available in the British Museum.

The uterus was bipartite as in al cetaceans. Including the vagina the corpus was $70 \mathrm{~cm}$ long and had a collapsed diameter of $6.0 \mathrm{~cm}$. The right cornu was 63 $\mathrm{cm}$ long with collapsed diameter $7.5 \mathrm{~cm}$. The left had a collapsed diameter of $7.0 \mathrm{~cm}$. A piece of the uterine wall from the right cornu, probably the formerly pregnant one, was fixed in Bouin's fluid as specimen SH 165.

The teats were not protruded but were in two fleshylipped grooves, $27 \mathrm{~cm}$ apart, a little behind the middle of the vulva and on either side of it. After flensing the mammary glands were exposed; they were reddishbrown in colour, $1.40 \mathrm{~m}$ long, $17 \mathrm{~cm}$ in greatest width and $7 \mathrm{~cm}$ in greatest depth. The glands extended forwards from the level of the vulva.

This description, so far as it goes, does not differ from Bouvier's elaborate account of the female reproductive system in H. ampullatus (1892, p.300 ff). Table 1 records those proportional measurements of the female genitals from Bouvier's specimen where they are comparable with those of the present specimen of $H$. planifrons and they are seen to be very similar. The mammary glands were more substantial in the present specimen, to be expected in a lactating whale.

The sexual cycle of $H$. ampullatus has been described by Benjaminsen and Christensen (1979) but nothing can be said about it here from this single specimen of $H$. planifrons.

\section{Diatoms and parasites}

The diatom film previously mentioned (p.84) showed as dirty yellow, ill-defined patches mostly on the snout and on the back. A sample (specimen SH 161) was identified by the late Dr T.J. Hart as Cocconeis ceticola f. constricta. In the North Pacific this diatom also occurs on sperm whales (Nemoto, 1956) so presumably it occurs also on the northern bottlenose. Nemoto et al. (1980) also found this variety on a southern bottlenose whale from East London, South Africa and considered this was evidence that $H$. planifrons migrates from the Antarctic or sub-Antarctic to warmer waters. The only other external parasites, if they may be called so, were the white, oval scars, about seven to eight centimetres long, which are well known to occur in blue, fin and sperm whales in the Antarctic. Their origen is still unknown although Pike (1951), Nemoto (1955) and Utrecht (1959) have attributed them to lampreys; Kreft (1953) suggested remoras, Ivashin and Golubovsky (1978) thought they are scars left by the stalked barnacle Penella when it drops off. Schevchenko (1970) and Jones (1971) believed they are caused by small sharks of the genus Isistius, and this explanation is now generally 
accepted. In any case it is agreed that the scars arise in warm waters. I counted about 50 of these scars on one flank of the present specimen; all were completely healed. No cyamids were found on the skin.

Of internal parasites there were no nematodes in the stomach and intestine of the Anisakis kind so common in sperm whales. But the kidneys were heavily infested by long, yellow, translucent, glistening nematodes which crammed the large renal blood vessels in entangled masses which could be extracted by handfuls. Specimens were preserved as SH 162 and were identified by Dr H.A.Baylis of the British Museum (Natural History) as Crassicauda bennetti (Spaul, 1926). Spaul's original specimens came from Hyperoodon and there is reason to believe that this was a stranded $H$. planifrons.

\section{UNCERTAINTY IN IDENTIFYING THE SPECIES AT SEA}

On an expedition in 1958 I identified five H. planifrons at sea in $33^{\circ} \mathrm{S}$ off the coast of Chile (R. Clarke, 1962). And R. Clarke, et al. (1978) explained that I could make this identification because I had examined the present specimen and had compared it with the whale I had observed at sea on 26 November 1947. No other observers to the present time have had this experience although many have identified, rightly or wrongly, whales they have believed to be $H$. planifrons. It happens that Hyperoodon can be confused with other ziphioid whales at sea. This is well explained by Brown on p. 5 of Brown and Gaskin (1967), describing a voyage to observe whales in the Antarctic:

“The title 'bottlenose' however, includes without distinction whales which were certainly or probably the southern bottlenose whale (Hyperoodon planifrons), and Berardius arnuxi and, as indicated in the table, other ziphioid whales which may have belonged to the genera Ziphius or Mesoplodon."

Recently Van Waerebeek et al. (2005) have recommended that attemps to recognize ziphiid species should be avoided at distances exceeding 0.8 miles.

Marcuzzi and Pilleri (1971, Figures 15 and 16) and Mead (1989, Figure 8) have illustrated the distribution of the northern and southern bottlenose whales, mostly in high latitudes north and south, but Mead added three marks of interrogation distributed in the equatorial Pacific as being possible records of $H$. planifrons. Since Mead's extensive review there have been reports of whales believed to be Hyperoodon from tropical latitudes, from the Gulf of California (Urban et al., 1994) and from the Indian Ocean (Leatherwood and Reeves, 1989; Ballance et al., 1997). I am here concerned with all these possible tropical records. Pitman et al. (1999, Table 1) have collected 45 records from the tropical Pacific between $35^{\circ}$ $\mathrm{N}$ and $7^{\circ} \mathrm{S}$, not only from published papers but from cetacean surveys by the U.S. Government and by Japan, and from sighting records by observers on tuna vessels. The field identifications were recorded as 'Unidentified beaked whale', 'Hyperoodon-like', 'Hyperoodon sp'
'Hyperoodon planifrons' (with and without a question mark) and 'possibly Indopacetus pacificus (Moore, 1968)'. Dalebout et al. (2003) have examined six specimens of Indopacetus pacificus and shown by DNA analysis that it is a valid species. Pitman et al. think it may be what they call the 'tropical bottlenose whale' shown in their Fig. 1 to inhabit the tropical Pacific and Indian Oceans. Leatherwood et al. (1988) first called this whale the tropical bottlenose. Pitman et al. have tried to differentiate it from other ziphioids, especially Hyperoodon, by comparing observations at sea, including behaviour. They conclude (p.545) that 'it is either an undescribed species, perhaps of the genus Hyperoodon, or Indopacetus pacificus.' Now Dalebout et al. (2003, p.454) consider, from the colour pattern, that the tropical bottlenose whale is indeed Indopacetus pacificus. It is significant that, although almost all the records in Pitman et al.'s Table 1 come from $35^{\circ} \mathrm{N}$ to the equator, there is no mention of Hyperoodon ampullatus. Presumably this is because the migration of $H$. ampullatus southward in winter, although poorly known, is believed to reach no further south than the lower latitudes of the North Atlantic (Benjaminsen and Christensen, 1979), although Ruud (1937) has recorded northern bottlenose whales from the Cape Verde Islands as far south as $15^{\circ} \mathrm{N}$.

Then whales which appear to be of the genus Hyperoodon have been recorded from tropical latitudes both north and south. This means that there is a possibility of genetic continuity between the northern and southern hemispheres. Therefore the speciation of Hyperoodon should now be discussed.

\section{Discussion}

The foregoing pages have shown that the present specimen of the female $H$. planifrons does not differ from what is known of the female $H$. ampullatus in morphometry, body colour, external characters, digestive system and reproductive system and parasites; and both species eat the same kind of food. Then if the northern and southern bottlenoses cannot be distinguished on the ground or on the flensing deck then they can certainly not be distinguished at sea. If there is any difference it may be in the skeleton, and especially in the skull since Flower (1882) based his new species Hyperoodon planifrons solely on a wave-and-pebble worn skull found in the Dampier Archipelago off northwest Australia.

Table 3 compares the vertebral formulae and the digital formulae from the flipper in northern and southern bottlenose whales as recorded by Nishiwaki (1972) and Arvy and Pilleri (1983). Skeletal material from the southern bottlenose will have come from stranded specimens. The trifling differences between the vertebral and digital counts for the two species are no greater than differing counts within species by the three or four authorities mentioned by Arvy and Pilleri and summarised in Table 3. Coming now to the skull I know only of one precise comparison of the skulls of $H$. 
Table 3. Vertebral and digital formulae of Hyperoodon ampullatus and H.planifrons compared from Nishiwaki (1972) and Arvy \& Pilleri (1983).

\begin{tabular}{|c|c|c|c|c|}
\hline \multirow[t]{2}{*}{ REFERENCE } & \multicolumn{2}{|c|}{ VERTEBRAL FORMULA } & \multicolumn{2}{|c|}{ DIGITAL FORMULA } \\
\hline & H. ampullatus & H. planifrons & H. ampullatus & H. planifrons \\
\hline $\begin{array}{l}\text { Nishiwaki } \\
(1972)\end{array}$ & $\begin{array}{c}\mathrm{C}^{7}+\mathrm{T}^{9}+\mathrm{L}^{9-11}+\mathrm{Ca}^{18-20}=43- \\
46\end{array}$ & $\mathrm{C}^{7}+\mathrm{T}^{9}+\mathrm{L}^{10}+\mathrm{Ca}^{20}=46$ & I: 1, II:5, III:5, IV:4, V:2 = 17 & $\begin{array}{l}\text { I:2, III:6, IIII:5, IV:4-5,V:3 } \\
=20-21\end{array}$ \\
\hline \multirow[t]{2}{*}{$\begin{array}{l}\text { Arvy \& } \\
\text { Pilleri (1983) }\end{array}$} & $\begin{array}{l}\mathrm{C}^{7}+\mathrm{T}^{9}+\mathrm{L}^{9-12}+\mathrm{Ca}^{17-20}=42- \\
48\end{array}$ & $\begin{array}{l}\mathrm{C}^{7}+\mathrm{T}^{8-9}+\mathrm{L}^{10-11}+\mathrm{Ca}^{17-20}=42- \\
46\end{array}$ & $\begin{array}{l}\text { I:1, II:5, III:4-5, IV:3, V:2 = } \\
15-16\end{array}$ & $\begin{array}{l}\text { I:2, II:7, III:6, IV:5, V:3 = } \\
23\end{array}$ \\
\hline & $\begin{array}{l}\text { Summary from four } \\
\text { authorities }\end{array}$ & $\begin{array}{l}\text { Summary from four } \\
\text { authorities }\end{array}$ & $\begin{array}{l}\text { Summary from three } \\
\text { authorities }\end{array}$ & From one authority \\
\hline
\end{tabular}

ampullatus and H. planifrons: Fraser (1945) compared a skull of a female southern bottlenose from South Georgia with skull material of the female northern bottlenose. The main difference was the relatively low development of the maxillary crests in the southern bottlenose which prompted Flower (1882) to give the specific name planifrons. Fraser's Table 1 shows that his H. planifrons skull was rather smaller than the $H$. ampullatus skull he used. I enter into no further details: Mead (1989, p.327) has summarised the differences observed by Fraser.

I have had in mind that further comparisons of Hyperoodon skulls, coming from whales of similar ages and both sexes of the two species, might show that the skull differences disappear so that only one species of Hyperoodon might join the sperm whale and the killer whale which wander the oceans of the world through tropical and temperate seas to the ice edge north and south. But Dalebout et al. (2004), applying DNA sequences in molecular taxonomy, have now shown that all 21 species of ziphiid whales are valid. So I must now admit that the genus Hyperoodon comprises two species, $H$. ampullatus and $H$. planifrons.

\section{Acknowledgments}

I am especially indebted to the late Captain Konrad Granøe, master and manager of Floating Factory Southern Harvester in 1947/48. In the midst of a busy Antarctic whaling season he gave permission for the bottlenose whale to be shot, flensed and dismembered for me. I thank fangst-løder Captain T. Olsen who shot the whale and I remember with pleasure my excursion with Captain Johan Antonsen in the whalecatcher Satsa when we observed bottlenose whales. Messrs Christian Salvesen, owners of the Southern Harvester, provided facilities. I thank Dr. Koen Van Waerebeek CEPEC Museo de Delfines, Pucusana, Perú, Dr Alan Baker, 8 Waters Lane, RD 2 Kerikeri, Bay of Islands, New Zealand and Dr. Natalie Goodall, Centro Austral de
Investigaciones Científicas, 9410 Ushuaia, Tierra del Fuego, Argentina who have kindly reviewed the text and made helpful comments. I am especially indebted to Dr. Van Waerebeek who brought to my attention the 'ovoid volume formula' and the very significant paper by Dalebout et al. (2004). Mr. Mauricio Polito kindly digitalised all original hand drawings I made for this manuscript, for which I am extremely grateful. I thank my wife the Peruvian whale biologist Obla Paliza for criticism of the text.

\section{References}

ARVY, L. AND Pilleri, G. (1983) Quatre cents ans d'observaciones sur l'hyperoodon, le cachalot et l'orque. Investigations on Cetacea. 15. Supplement. 265 pp.

AsH, C. (1962) Whaler's eye. George Allen \& Unwin, London. $136 \mathrm{pp}$.

Ballance, L.T., Pitman, R.L. and Reilly, S.B. (1997) Cetacean observations in the western tropical Indian Ocean, March-July 1995. Paper SC/48/08 presented to the IWC Scientific Committee May 1997. (unpublished) [Paper available from the IWC office].

BAUSSARD, M. (1789) Sur deux cetacés echoués? vers Honfleur, le 19 septembre 1788. Observations sur la Physique, sur l'Histoire Naturalle et sur les Arts 34: 202-206.

BEDDARD, F.E. (1900) A Book of Whales. John Murray, London. xii, $320 \mathrm{pp}$.

Benjaminsen, T. and Christensen, I. (1979) Pages 143-164 in WinN, H.E. AND OlLA, B.L. (Eds) The Natural History of the Bottlenose Whale Hyperoodon ampullatus (Forster). in Behaviour of Marine Animals. Vol. 3. Cetaceans. Plenum Press, New York and London. xix, $438 \mathrm{pp}$.

BOUVIER, E.L. (1892) Observations anatomiques sur l'Hyperoodon rostratus. Annales des Sciences Naturelles Zoologie et Paléontologie Series 7. 13: 259-320.

BROWN, S.G. AND GASKIN, D.E. (1967) Report on whale observations in the Antarctic 1966/67. FAO Fisheries Circular No. 111.v, $45 \mathrm{pp}$.

\footnotetext{
${ }^{1}$ Mead's Fig. 2 includes the photographs G-I which show the skull of the present specimen. His legend '...captured 10 February 1947 at

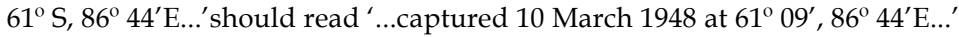


Christensen, I. (1973) Age determination, age distribution and growth of bottlenose whales Hyperoodon ampullatus (Forster) in the Labrador Sea. Norwegian Journal of Zoology 21:331-340.

CLARKE, M.R. (1962a) Significance of cephalopod beaks. Nature 193: 560-561.

CLARKE, M.R. (1962b) The identification of cephalopod 'beaks' and the relationship between beak size and total body weight. Bulletin of the British Museum (Natural History). 8: 419-480.

CLARKE, R. (1962) Whale observation and whale marking off the coast of Chile in 1958 and from Ecuador towards and beyond the Galápagos Islands in 1959. Norsk Hvalfangst-Tidende 7: 265-287.

CLARKE, R. (2005) Male nipples in blue and fin whales and their absence in sperm whales. Aquatic Mammals 31: 124-132.

Clarke, R., Aguayo L., A. and Basulto del CAmpo, S. (1978) Whale observation and whale marking off the coast of Chile in 1964. Scientific Reports of Whales Research Institute, Tokyo 30: 117-177.

Clarke, R. and Paliza, O. (1988) Intraspecific fighting in sperm whales. Reports of the International Whaling Commission 38: 235-241.

Clarke, R., Paliza, O. and Aguayo, L.A. (1988) Sperm whales of the Southeast Pacific. Part IV: Fatness, food and feeding. Investigations on Cetacea 21: 53-195.

DALE, S. (1730) The History and Antiquities of Harwich and Dovercourt, topographical, dynastical and political, first collected by Silas Taylor, alias Douville and now much enlarged in all its parts by Samuel Dale. Davis \& Green, London. 464 pp.

DALEBOUt, M.L., Ross, G.J.B., BAKER, C.S., ANDERSON, R.C., BEST, P.B., CockCroft, V.G., Hinsz, H.L., Peddemors, V. ANd PitMan, R.L. (2003) Appearance, distribution, and genetic distinctiveness of Longman's beaked whale, Indopacetus Pacificus. Marine Mammal Science 19: 421-461.

DALebout, M.L., BAKER, C.S., MEAD, J.G., CockCRoft, V.G. and YAMADA, T.K. (2004) A Comprehensive and validated molecular taxonomy of beaked whales, family Ziphiidae. Journal of Heredity 905: 459-473.

DIXON, J.M., FRIGO, L. AND MOYLE, R.L.C. (1994) New information on the southern bottlenose whale, Hyperoodon planifrons (Cetacea: Ziphiidae) from a recent stranding in Victoria, Australia. Australian Mammalogy 17: 85-95.

Eudes-Deslongchamps, M. (1842) Remarques zoologiques et anatomiques sur l'Hyperoodon. Mémoires de la Société Linnéenne de Normandie 7: 1-18.

ESCHRICHT, D.F. (1849) "Über die shanabelwalle Rhynchoceti, die 'Zahnlosen Delfine' Schegels, Hyperoodontina Gray's im allegemeinen und den entenwall (Chaenocetus rostratus, Hyperoodon rostr. Anctorum, un besondern. Vol. 1, pp. 25-55 in Zoologisch-anatomisch-physiologische Untersuchungen über die nordischen Wallthiere, Leopold Voss, Leipzig.

Fischer, P. (1881) Hyperoodon Lacépede. Pages 100-103 in Les Cétacés du sud-ouest de la France. Actes de la Société. Linnéenne de Bordeaux, 5.

FLOWER, W.H. (1882) On the cranium of a new species of Hyperoodon from the Australian Seas. Proceedings of the Zoological Society, Lond. 392-396.

FORSTER, J.R. (1770) Footnote on P. 18 of P. Kelm, 1770-71, Travels into North America, 3 vols. London. The footnote gave Balaena ampullata now Hyperoodon ampullatus (Forster, 1770).
FRASER, F.C. (1937) Cetaceans. Part II. Pages. 203-349 in Norman, J.R. AND FRASER, F.C. (Eds) Giant Fishes, Whales and Dolphins, xvii, $349 \mathrm{pp}$.

FRASER, F.C. (1945) On a specimen of the southern bottlenosed whale Hyperoodon planifrons. Discovery Reports 23: 19-36.

FRASER, F.C. (1964) Whales and Whaling. Pages 191-205 in Priestley, R.E., Adie, R.T. and RobIn, G. DE Q. (Eds) Antarctic Research, Butterworths, London.

Gianuca, N.M. AND CASTELLO, H.P. (1976) First record of the southern bottlenose whale, Hyperoodon planifrons from Brazil. Scientific Reports of Whales Research Institute, Tokyo 28: 119-126.

Goodall, R.N.P. AND GaleazzI, A.R. (1985) A Review of the Food Habits of the Small Cetaceans. Pages 566-572 in SIEGFRIED, W.R., Condy, P.R. AND LAws, R.M. (Eds) Antarctic Nutrient Cycles and Food Webs. Springer-Verlag Berlin, Heidelberg.

GRAY, D. (1882) Notes on the characters and habits of the bottlenose whale (Hyperoodon rostratus). Proceedings of the Zoological Society, London, 726-731.

HALE, H.M. (1931) Beaked whales- Hyperoodon planifrons and Mesoplodon layardii from South Australia. Records of the South Australian Museum 4: 291-311.

Hale, H.M. (1939) Rare whales in South Australia. South Australian Naturalist 19: 5-8.

HART, T.J. (1935) On the diatoms of the skin film of whales and their possible bearing on problems of whale movements. Discovery Reports 10: 247-282.

HUNTER, J. (1787) Observations on the structure and oeconomy of Whales. Philosophical Transactions 77: 371-450.

International Whaling Commission (1989) Report of the SubCommittee on Small Cetaceans. Reports of the International Whaling Commission 39: 117-126.

IVAshin, M.V. and Golubovsky, Yu. P. (1978) On the cause of white scars on the body of whales. Reports of the International Whaling Commission 28: 199.

JАСОВ, A. (1825) On the generic characters and anatomical structure of the whale, entitled Delphinius Diodon by Hunter and Hyperoodon by La Cepede. Dublin Philosophical Journal 1: 58-73.

JONES, E.C. (1971) Isistius brasilienses, a squaloid shark, the probable cause of crater wounds on fishes and cetaceans. Fishery Bulletin, U.S. 69: 791-798.

Kasamatsu, F. (1991) Current occurrences of toothed whales and abundance of beaked whales in the Antarctic. IBI Reports 2: 75-77.

KASAMATSU, F. (1993) Summary of studies on distribution, migration and abundance of cetacean populations occurring in the Antarctic waters. Paper SC/45/SHBa4 presented to the IWC Scientific Committee, May, 1993- 115 pp. (unpublished). [Paper available from the IWC Office].

Kasamatsu, F., Hembree, D., Joyce, L., Tsunoda, R., Rowlett, R. AND NAKANO, T. (1988) Distribution of cetacean sightings in the Antarctic: Results obtained from the IWC/IDCR minke whale assessment cruises, 1978/79 to 1983/84. Reports of the International Whaling Commission 38: 449-487.

Kasamatsu, F. And Shigemune, H. (1989) Preliminary report of the second minke whale sighting surveys in low and middle latitudinal waters in the Southern Hemisphere in 1988/89. Paper SC/41/ SHMi15 presented to the IWC Scientific Committee, San Diego, 1989 (unpublished). [Paper available from the IWC Office]. 
KREFFT, G. (1953) Ichthyologische Mitteilungen aus dem Institut für Seefischerei der Bundesanstalt für Fischerei. I. Zoologischer Anzeiger 150: 275-282.

LEATHERWOod, S. AND REEVES, R.R. (Eds) (1989) Marine Mammal Research and Conservation in Sri Lanka, 1985-1986. Nairobi, Kenya, United Nations Environment Programme, Marine Mammal Technical Report, Number 1. vi $138 \mathrm{pp}$.

Liouville, J. (1913) Genre Hyperoodon Lacépede. Pages 140-151 in Cetacés de l'Antarctique (Baleinoptéres, Ziphiidés, Delphinidés). Deuxieme Expédition Antarctique Francáise (1908-1910). Paris. 276 pp.

MarcuzzI, G. and Pilleri, G. (1971) On the zoogeography of Cetacea. Investigations on Cetacea 3, Part I: 101-170.

MeAD, J.G. (1989) Bottlenose Whales Hyperoodon ampullatus (Forster, 1770) and Hyperoodon planifrons (Flower, 1882). Pages 321-348 in RIDGEWAY, S.H. AND HARRISON, R. (Eds). Handbook of Marine Mammals. Vol. 4. River Dolphins and the Larger Toothed Whales. Academic Press, San Francisco, California. xix, 442 pp.

MOORE, J.C. (1968) Relationships among the living genera of beaked whales with classifications, diagnoses and keys. Fieldiana Zoology 53: 209-298.

NЕмото, T. (1955) White scars on whales (1) Lamprey Marks. Scientific Reports of Whales Research Institute, Tokyo 10: 69-77.

NEMOTO, T. (1956) On the diatoms of the skin film of whales in the Northern Pacific. Scientific Reports of Whales Research Institute, Tokyo 11: 99-124

Nemoto, T., Best, P.B., Ishimaru, K. AND TAKano, H. (1980) Diatom films on whales in South African waters. Scientific Reports of Whales Research Institute, Tokyo 32: 97-103.

NisHIWAKI, M. (1972) General Biology. Pages 3-204 in S.H. Ridgway (ed.) Mammals of the Sea: Biology and Medicine. Charles C. Thomas, Springfield, Illinois. xii $+812 \mathrm{pp}$.

OHLIN, A. (1893) Some remarks on the bottlenose whale (Hyperoodon). Acta Universitatis Lundensis 29: 1-13.

OHSUMI, S., KaWASAKI, M. AND NISHINAKI, S. (1995) Biological results of beaked whales surveyed by Japanese whale research programme under special permit in the Antarctic and the need of their research take. Paper SC/46/SM15 presented to the IWC Scientific Committee, May 1995. (unpublished, 24 pp.). [Paper available from the IWC. office].

Perrin, W.F. AND MYrick JR, A.C. (Eds) (1980) Age Determination of Toothed Whales and Sirenians. Reports of the Workshop, Pages 1-50 in Reports of the International Whaling Commission, Special Issue 3. viii $+229 \mathrm{pp}$.

PIKE, G.C. (1951) Lamprey marks on whales. Journal of the Fisheries Research Board of Canada 8: 275-280.

PitMan, R.L., Palacios, D.M., BRENNAN, L.R., BRENNAN, B.J., BALCOLM III, K.C. AND MiYashita, T. (1999) Sightings and possible identity of a bottlenose whale in the tropical Indo-Pacific: Indopacetus pacificus? Marine Mammal Science 15: 531-549.

Racovitza, E.G. (1903) Cetacés. Expédition Antarctique Belge, Zoologie $142 \mathrm{pp}$.

Ross, SIR J.C. (1847) A voyage of discovery and research in the Southern and Antarctic Regions during the years 1839-1843. Murray, London. Vol. I, 336 pp; Vol. II, 447 pp.

Ross, G.J.B., BAKER, A.N., GOODALL, R.N.P., LiCHTER, A.A. AND MEAD, J.G. (1989) The distribution of beaked whales in the southern hemisphere. Reports of the International Whaling Commission 39: 468 (Resume Section. Full text available from the IWC Office).
Ruud, J.T. (1937) Bottlenosen, Hyperoodon rostratus (Muller). Norsk Hvalfangst-Tidende 26: 456-458.

SAPIN-JaLOUSTRE, J. (1953) L'identificatión des cetacés antarctiques á la mer. Mammalia 17: 221-259.

SCHEFFER, V.B. (1969) Marks on the skin of a killer whale. Journal of Mammalogy 50:151.

SEKIGUCHI, K., KLAGES, N., FINDLAY, K. AND BEST, P.B. (1992) Feeding habits and possible movements of southern bottlenose whales (Hyperoodon planifrons). Proceedings of the NIPR Symposium on Polar Biology 6: 84-97.

SCHEVCHENKO, V.I. (1970) A riddle of white scars on the body of whales. Priroda 6: 72-73.

SPAUL, E.A. (1926) Crassicauda bennetti, sp. n., a new nematode parasite for the bottlenosed whale (Hyperoodon). Annals and Magazine of Natural History, Ser.9, 17: 581-585.

TIETZ, R.M. (1966) The southern bottle-nose whale Hyperoodon planifrons, from Humewood, Port Elizabeth. Annals of the Cape Provincial Museum (Natural History) 5: 101-107.

Tomilin, A.G. and LatysheV, V.M. (1967) Novye dannye o ploskolobom butylkonose Hyperoodon planifrons Flower 1882. [New data on the flat-fronted bottlenose - Hyperoodon planifrons Flower 1882] Moskovskava Obshchestba Ispytately Prirody; Byulleten Otdel Biolologicheskii 72: 119-122.

TURNER, SIR W. (1886) On the occurrence of the bottle-nosed, a beaked whale (Hyperoodon rostratus) in the Scottish Seas, with observations on its external characters. Proceedings of the Royal Physiographic Society., Edinburgh 9: 25-47.

TURNER, SIR W. (1889) Additional observations on the stomach in the ziphioid and delphinoid whales. J. Anat. Phys. 23: 466-492.

URBAN, R., RAMíREZ, S. AND SALINAS V., J.C. (1994) First record of bottlenose whales, Hyperoodon sp. in the Gulf of California. Marine Mammal Science 10: 471-473.

UTRETCH, W.L. VAN. (1959) Wounds and scars in the skin of the common porpoise, Phocaena phocaena (L.). Mammalia 23: 100-122.

VAN WAerebeek, K., LeAPER, R., BAKER, A.N., PAPASTaVRou, V. AND THIELE, D. (2004) Odontocetes of the Southern Ocean Sanctuary. Document SC/56/SOS1: IWC Scientific Committee Meeting, Sorrento, Italy, June 2004 (Unpublished, 13 pp.)

VAN WAEREBEEK, K., FindLAY, K., FRIEDRICHSEN, G. AND BeST, P. (2005) Bold colouration pattern in southern bottlenose whales: a preliminary assessment of external variation. Document SC/57/SM12: IWC Scientific Committee Meeting, Ulsan, Korea, May-June 2005 (Unpublished, 9 pp.)

VROLIK, W. (1848) Naturren onleedkundige beschouwing van der Hyperoodon. Hollandische Maatshappij der Wetenschappen te Haarlem, Twade Vergandelinge, $2^{\text {nd }}$ Ser. 5: $128 \mathrm{pp}$. Haarlem.

WEBER, M. (1886) Studien über Saugethiere. Ein Beitrag zur Frage nach dem Ursprung der Cetaceen. Fischer edit. Stuttgart.

WiLSON, (1907) Cetacea. Report of the National Antarctic Expedition, 1901-1904. Nat. Hist. Vol. II, Zoology I, Mammalia. Pp 1-9. British Museum (Nat. Hist.).

ZEMSKII, V.A. AND BUDYLENKO, G.A. (1970) Ploskolobye batylkonosy iz Antarktiki [The flat-headed bottlenose in the Antarctic]. Pages 193-202 in Zemskii, V.A. (Ed.) Kity Iuzhnovo Polushariia. Trudy Atlant NIRO, No. 29, 234 pp

Received 21 March 2005. Accepted 23 November 2005. 